\section{Durian Fruit Dehiscence-Water Status and Ethylene}

\author{
Siriphun Sriyook, Somboon Siriatiwat, and Jingtair Siriphanich \\ Department of Horticulture, Kasetsart University, Kamphaengsaen Campus, \\ Nakhon Pathom, Thailand 73140
}

Additional index words. Durio zibethinus, postharvest physiology, storage, growth regulators, coating material, water loss

\begin{abstract}
Immature and mature durian (Durio zibethinus Murr.) fruit dehiscence was studied. Fruit were stored at $27 \mathrm{C}$ and $65 \%$ or $95 \%$ relative humidity, with or without 24 hour exposure to $100 \mathrm{ppm}$ ethylene. Low relative humidity and ethylene increased fruit dehiscence. Spraying fruit with $100 \mathrm{ppm} \mathrm{GA}_{3}$ delayed dehiscence but allowed pulp ripening to continue. The plant-growth regulators IBA; 2,4-D; 2,4,5-T; BAP; daminozide; and mepiquat chloride had no consistent effects on fruit dehiscence. Various coating materials delayed dehiscence and ripening; a sucrose fatty acid ester at $1 \%$ concentration gave the best result. All coating materials reduced weight loss $7 \%$ to $14 \%$ below that of the control fruit. Fruit coated with the sucrose fatty acid ester and $100 \%$ apple wax had higher internal $\mathrm{CO}_{2}$ levels than fruit coated with any other coating. Ethylene is more important in durian fruit dehiscence than weight loss. Chemical names used: 3-indolebutyric acid (IBA); 2,4-dichlorophenoxyacetic acid (2,4-D); 2,4,5-trichlorophenoxyacetic acid $(2,4,5$ T); 6-benzylaminopurine (BAP); succinic acid-2,2-dimethyl hydrazide (daminozide); 1,1dimethyl-piperidinium chloride (mepiquat chloride); gibberellic acid $\left(\mathbf{G A}_{3}\right)$.
\end{abstract}

Durian is an important tropical fruit in southeastern Asia. In 1990, it was the major fresh fruit export from Thailand, valued at $\$ 10$ million (Dept. of Customs, 1991); the main markets are Hong Kong and Singapore. This climacteric fruit has distinct respiration and ethylene production peaks (Booncherm, 1991; Tongdee et al., 1990). A major postharvest problem of fully ripe durian fruit is dehiscence along the suture in the middle of each locule. Consumers in Singapore prefer fully ripe durian with no splitting; however, Thai consumers prefer less-ripe fruit with a relatively firm pulp texture and a milder scent. Partially ripe durian fruit are difficult to open because the abscission zone along the suture has not fully developed. Splitting fruit with mechanical aids works only on ripe fruit and sometimes damages the pulp.

For most dehiscent fruit, such as pecan [Carya illinoinensis (Wangenh) K. Koch], the suture opens because of shrinkage associated with water loss from the tissue (Wood, 1986). In pistachio (Pistacia vera L.), shell dehiscence depends on seed growth and development and is not the result of the seed exerting force on the surrounding endocarp (Crane and Iwakiri, 1982). Instead, it results from abscission triggered by some substance(s) emanating from the seed. In durian fruit, an abscission

Received for publication 15 July 1993. Accepted for publication 4 Mar. 1994. Funding of this research was supported by Kasetsart Univ. Research and Development Institute. We gratefully acknowledge Suranant Subhadrabandhu and Adel A. Kader for their critical review. The cost of publishing this paper was defrayed in part by the payment of page charges. Under postal regulations, this paper therefore must be hereby marked advertisement solely to indicate this fact.

HortScience, Vol. 29(10), OCtober 1994
A commercial orchard in Klang district, Rayong province, on the eastern coast of Thailand provided 'Chanee' durian fruit. Fruit of the same size were tagged 10 days after full bloom, and they were $\approx 7$ to 13 days after anthesis. Fruit were harvested immature or mature in the morning, transported to Kamphaengsaen campus the same day, and used immediately for experiments. Five to 15 fruit were used per treatment. Unless otherwise stated, fruit were harvested at 110 days from anthesis.

Effect of weight loss. Durians were harvested 90 and 110 days after anthesis. Each fruit $(\approx 2 \mathrm{~kg})$ was placed in a metal container for 5 days with air at $65 \%$ or $95 \%$ relative humidity (RH) circulated at 2 liters $\cdot \mathrm{min}^{-1}$. To obtain $95 \% \mathrm{RH}$, air was bubbled through water before entering the container. For $65 \% \mathrm{RH}$, $100 \mathrm{~g}$ of silica gel was placed in the bottom of the container and replaced every $12 \mathrm{~h}$ to maintain RH at $60 \%$ to $70 \%$. A hygrometer (Nikei Co., Japan) was placed inside one container of each treatment. Temperature was maintained at $27 \pm 2 \mathrm{C}$

Effect of plant-growth regulators. For 24 $\mathrm{h}$, durian fruit were exposed to fresh moist air $(\approx 95 \% \mathrm{RH})$ or air containing $100 \mathrm{ppm}$ ethylene; then they were transferred to an open shelf at $27 \pm 2 \mathrm{C}$ and $70 \%$ to $80 \% \mathrm{RH}$. Another fruit set was sprayed with IBA (1000 or 5000 ppm); 2,4-D (100 or 1000 ppm); 2,4,5-T (100 or $1000 \mathrm{ppm}) ; \mathrm{GA}_{3}(10$ or $100 \mathrm{ppm}) ; \mathrm{BAP}(10$ or $100 \mathrm{ppm}$ ); daminozide (500 or $5000 \mathrm{ppm}$ ); mepiquat chloride (25 or $100 \mathrm{ppm}$ ); or water (as a control). Fruit were kept at $29 \pm 2 \mathrm{C}$ and $70 \%$ to $80 \%$ RH for 6 days.

Effect of coating materials. Four commercial coating materials were tested; a sucrose fatty acid ester, Semperfresh (Semper Biotechnology, London); apple wax and storage wax (solid content $=17.3 \%$ and $21.7 \%$, unknown composition) (Safepak Product, Kfarsaba, Israel); and Sta-fresh \#360 (shellac and rosin, solid content $=18.1 \%$ ) (FMC Corp. Lakeland, Fla.) at various concentrations according to the manufacturer's general recommendation (see Table 3). Fruit were handsprayed and then stored at $29 \pm 2 \mathrm{C}$ and $70 \%$ to $80 \%$ RH for 6 days. zone develops along the suture, and as the fruit cells (unpublished data)

Our goal is to report the role of weight loss, ethylene, and other plant-growth regulators on mercial coating materials in preventing durian dehiscence also is reported.

\section{Materials and Methods}

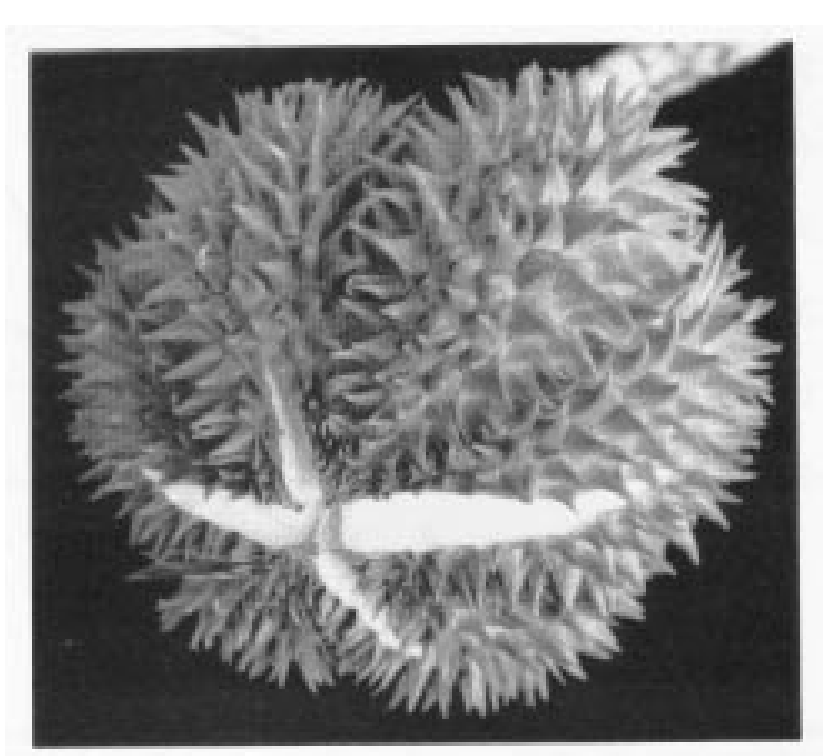

Fig. 1. Dehiscence in durian fruit starts at the stylar end and progresses to the stem end. 
Fruit dehiscence and quality evaluation. Durian dehiscence (Fig. 1) was assessed by estimating the proportion of each locule open $(0,1,2,3$, and $4=$ no dehiscence, $1 / 4,1 / 2$, $3 / 4$, and full length, respectively) and calculating a dehiscence score ( 0 to 20 , where $20=$ all locules dehisced from the stylar end to the fruit stem). Husk thickness was measured with a vernier caliper at the fruit equator. Pulp firm- ness was measured by removing the pulp (including the seed) from durian locules and pressing it with a firmness tester (modified from a commercial weight scale) (Teo Co., Bangkok, Thailand) with a plunger head $5 \mathrm{~mm}$ in diameter. Pulp soluble solids concentration (SSC) was measured with a hand-held refractometer (Atago Co., Tokyo) after blending the pulp with three volumes of water and centri-
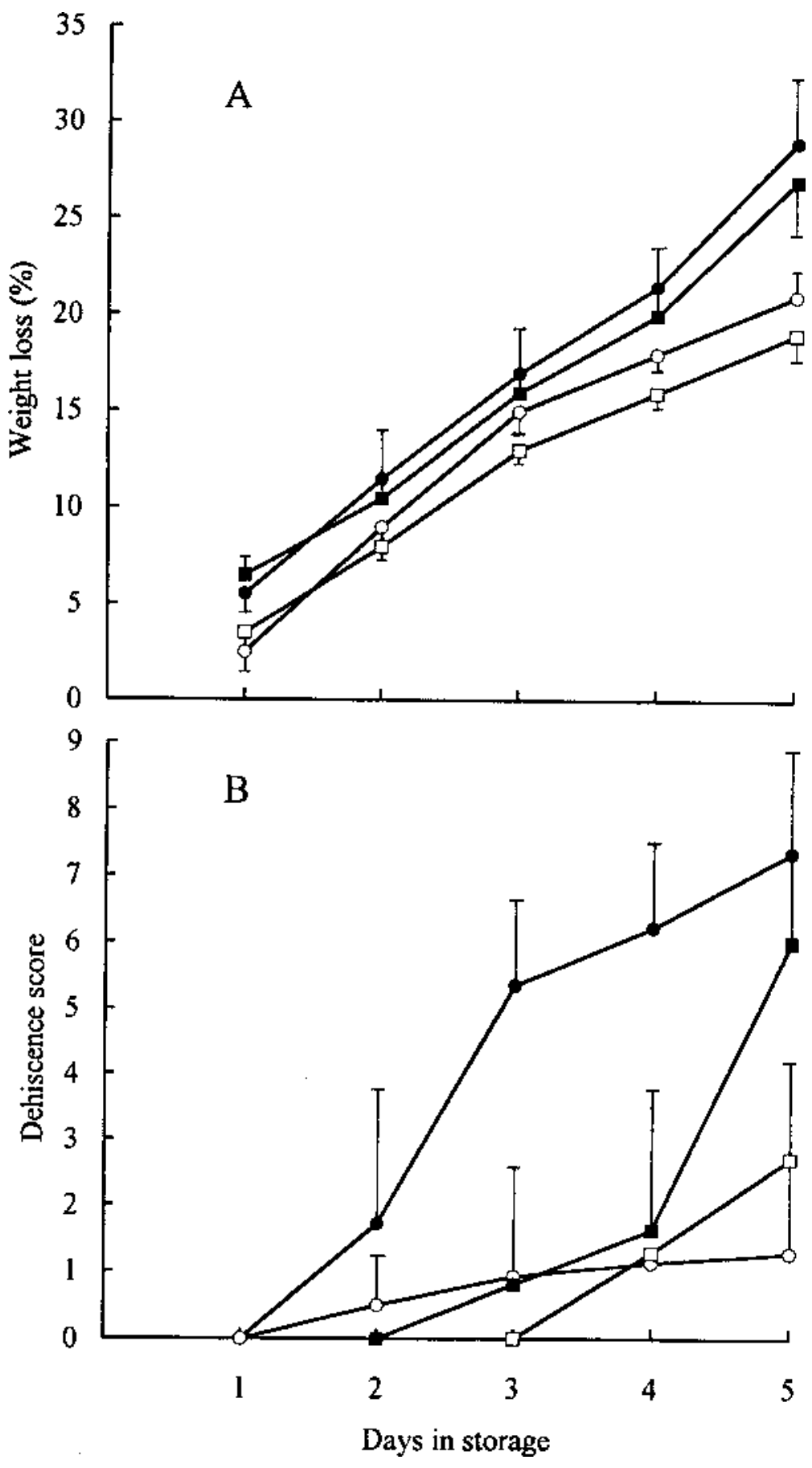

Fig. 2. (A) Effect of two relative humidities (RH) on weight loss and (B) dehiscence score of immature and mature durian fruit stored at $27 \mathrm{C}$. (-) Immature durian (90 days postanthesis), $65 \% \mathrm{RH}$; $(\mathrm{O})$ immature

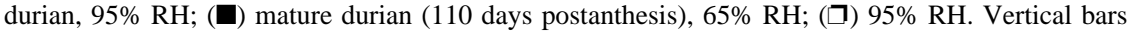
represent $\mathrm{SD}(\mathrm{n}=5)$.

fuging. Pulp color was estimated by comparing it to a color chart [The Royal Horticultural Society (RHS), London]. Starch was determined from dried pulp (Association of Official Analytical Chemists, 1984).

Internal gas determination. Gas was withdrawn from durian locules by submerging durian fruit under water and using a needle and syringe to extract gas. Gas concentrations were measured by gas chromatography with silica gel column and thermal conductivity detector for $\mathrm{CO}_{2}$ and Porapak $\mathrm{N}$ and flame ionization detector for ethylene.

\section{Results}

Relative humidity. Durian fruit weight loss was $\approx 4 \%$ per day, even at $95 \%$ RH. Five days after harvest, fruit lost $\approx 18 \%$ of its weight at the higher RH and $\approx 27 \%$ at the lower RH (Fig. 2A). Younger fruit ( 90 days postanthesis) lost more weight per unit weight than mature fruit. Durian fruit kept at or under $65 \% \mathrm{RH}$ for 5 days had a dehiscence score of 6 to 7 , but it was only 1 to 3 for fruit stored at the higher humidity (Fig. 2B). The immature fruit started to dehisce more quickly than mature fruit after harvest. High RH delayed the onset of dehiscence and reduced the splitting rate. No differences were noted in the pulp quality of the fruit kept at the two humidities. Mature fruit were softer and had a higher SSC than the immature fruit (Table 1). Pulp and seed color were similar in both treatments, but mature fruit had darker pulp and seed color; 15B and 20A vs. $16 \mathrm{D}$ and $18 \mathrm{~B}$ (RHS color chart). Husk thickness was similar at the two humidities and ranged from 5.3 to $6.7 \mathrm{~mm}$.

Plant-growth regulators. Weight loss was slightly higher in fruit treated with ethylene (Fig. 3A). The onset of dehiscence was advanced by $\approx 1$ day, and the rate of dehiscence was higher in ethylene-treated fruit than control fruit (Fig. 3B). Immature fruit took $\approx 3$ more days to dehisce than mature fruit. Ethylene treatment did not significantly enhance ripening as judged by pulp firmness (Table 1).

Table 1. Effect of storage at two relative $(\mathrm{RH})$ humidities and of a 24-h ethylene treatment on fruit pulp resistance to compression and soluble solids concentration (SSC) of durian fruit following 5 days of storage at $27 \mathrm{C}$.

\begin{tabular}{lccc}
\hline $\begin{array}{l}\text { Fruit } \\
\text { maturity }\end{array}$ & Treatment & $\begin{array}{c}\text { Pulp } \\
\text { firmness (N) }\end{array}$ & SSC (\%) \\
\hline \multirow{4}{*}{ Immature } & RH (\%) & & \\
& 65 & $6.08 \mathrm{a}^{\mathrm{z}}$ & $13.9 \mathrm{~b}^{\mathrm{z}}$ \\
Mature & 95 & $8.45 \mathrm{a}$ & $14.6 \mathrm{~b}$ \\
& 65 & $1.18 \mathrm{~b}$ & $23.8 \mathrm{a}$ \\
& 95 & $1.27 \mathrm{~b}$ & $23.4 \mathrm{a}$ \\
& Ethylene & & \\
Immature & $(\mathrm{ppm})$ & & \\
& 0 & $7.26 \mathrm{~m}$ & $15.0 \mathrm{n}$ \\
Mature & 100 & $5.69 \mathrm{~m}$ & $16.7 \mathrm{n}$ \\
& 0 & $7.16 \mathrm{~m}$ & $23.3 \mathrm{~m}$ \\
& 100 & $6.34 \mathrm{~m}$ & $21.3 \mathrm{~m}$
\end{tabular}

${ }^{2}$ Mean separation within columns and variables by Duncan's multiple range test at $P \leq 0.05$. 
Most of the plant-growth regulators tested had some effect on fruit dehiscence. Mepiquat chloride at $25 \mathrm{ppm}$ enhanced dehiscence relative to the control, but 100 ppm BAP significantly reduced dehiscence scores. Initial tests indicated that fruit treated with $1000 \mathrm{ppm}$ 2,4,5-T or $100 \mathrm{ppm} \mathrm{GA}_{3}$ did not dehisce (Table 2). A subsequent experiment showed that only $\mathrm{GA}_{3}$ delayed fruit dehiscence (data not shown). The $\mathrm{GA}_{3}$-treated fruit remained green until the end of the experiment ( 6 days), but the control fruit and fruit in the other treatments changed to yellow-green. Weight loss and SSC were similar for the various treatments. However, pulp of fruit treated with 2,4-D or 2,4,5-T was firmer than that from other treatments (Table 2).

Coating material. All coating materials used in this experiment significantly reduced weight loss. Fruit waxed with Semperfresh lost $\approx 40 \%$ as much weight as the control fruit (Table 3). At 9 days, all treated fruit had higher $\mathrm{CO}_{2}$ concentrations than the control fruit, except those treated with Sta-fresh \#360 wax at $20 \%$ (Table 3). On all three evaluation dates, ethylene concentration in fruit that were treated with $1 \%$ Semperfresh, $100 \%$ apple wax, and $100 \%$ storage wax was lower than the control fruit. Durian dehiscence was significantly reduced by these three coatings, with the Semperfresh resulting in no dehiscence. There was a reduction in flesh softening and starch degradation by most coatings; however, the increase in SSC was delayed only by Semperfresh (Fig. 4). Semperfresh also delayed the pulp yellowing by 3 days. No offflavor was detected in treated fruit. Aroma was milder at the end of the experiment in fruit treated with $1 \%$ Semperfresh than in control fruit or fruit in other treatments.

\section{Discussion}

Weight loss (Figs. 2 and 3) and subsequent shrinkage, which was easily observable, may provide a natural force to pull the fruit open. However, ethylene had a greater effect than weight loss on fruit dehiscence. Ethylene accelerated the onset of dehiscence in immature and mature fruit, suggesting that cell weakening in the separation zone had been induced. However, weight loss can cause stress ethylene production (Abeles, 1973), which may lead to weakening of the suture zone.

$\mathrm{GA}_{3}$ significantly delayed durian fruit dehiscence with no apparent effect on other ripening changes measured. This finding might be the result of $\mathrm{GA}_{3}$ failing to penetrate into the fruit's pulp or of evaluating ripening at a stage when treatment differences had already disappeared. However, Booncherm (1991) found that most of the ethylene and $\mathrm{CO}_{2}$ production occurred in the husk, with low rates in the pulp. Hence, $\mathrm{GA}_{3}$ could indirectly delay pulp ripening by delaying husk ripening. $\mathrm{GA}_{3}$ delayed color development in tomato (Lycopersicon esculentum Mill.) and banana (Musa sp.) without affecting other ripening processes (Dostal and Leopold, 1967; Vendrell, 1970). The mechanism by which $\mathrm{GA}_{3}$ delays durian fruit dehiscence is not known.
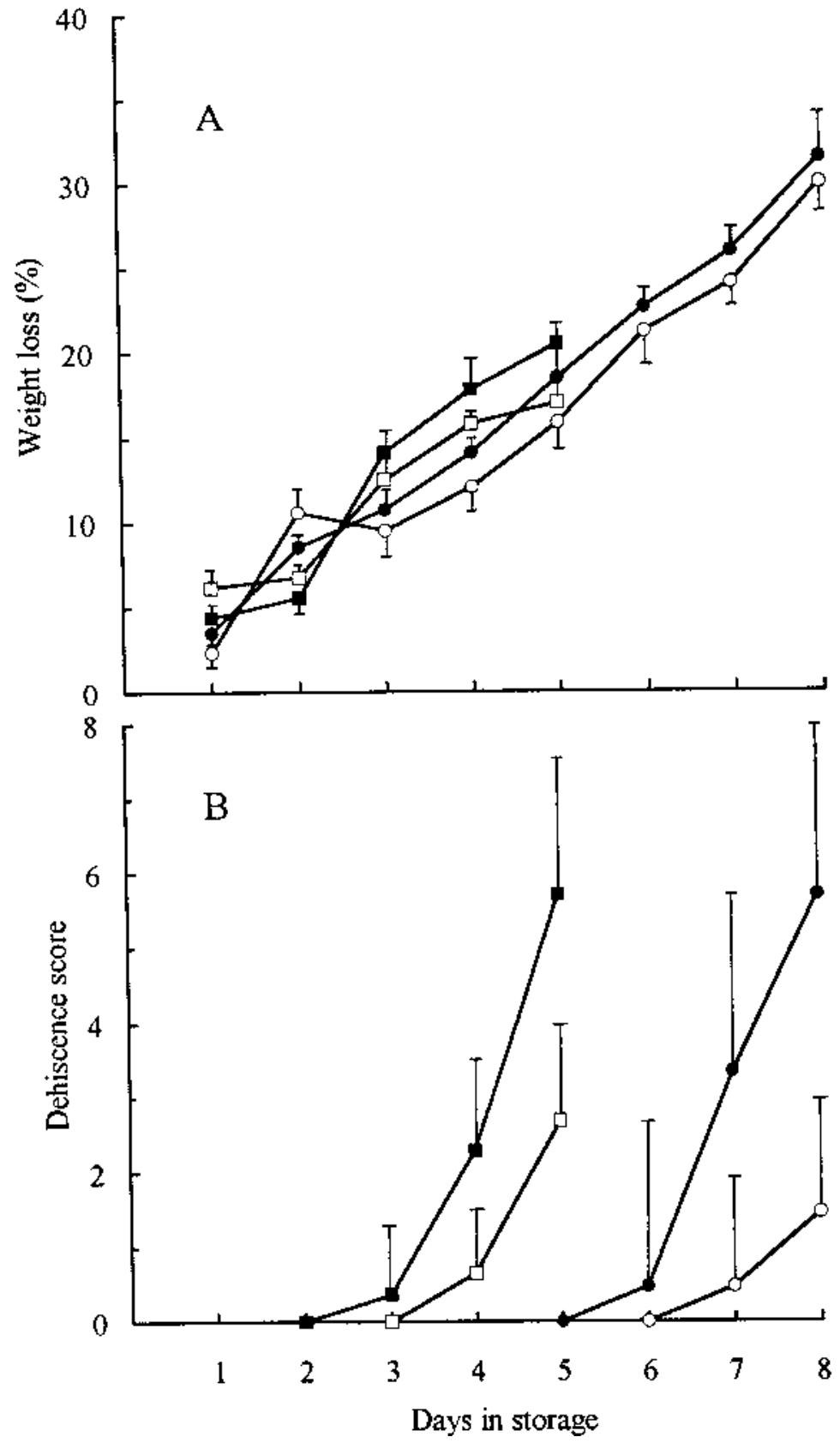

Fig. 3. (A) Effect of a 24-h ethylene treatment on weight loss and (B) dehiscence score of durian fruit stored at 27C. (○) Immature durian, 0 ppm C $\mathrm{H}_{4} ;(\boldsymbol{O}) 100 \mathrm{ppm} \mathrm{C}_{2} \mathrm{H}_{4} ;(\square)$ mature durian, $0 \mathrm{ppm} \mathrm{C}_{2} \mathrm{H}_{4} ;(\mathbf{\square}) 100$ ppm $\mathrm{C}_{2} \mathrm{H}_{4}$. Vertical bars represent SD $(\mathrm{n}=5)$.

Table 2. Effect of plant-growth regulators on dehiscence and pulp quality of durian fruit stored 6 days at 29C.

\begin{tabular}{lcccc}
\hline $\begin{array}{l}\text { Plant-growth } \\
\text { regulator }\end{array}$ & $\begin{array}{c}\text { Concn } \\
(\mathrm{ppm})\end{array}$ & $\begin{array}{c}\text { Dehiscence } \\
\text { score }\end{array}$ & $\begin{array}{c}\text { Dehisced } \\
\text { fruit }(\%)\end{array}$ & $\begin{array}{c}\text { Pulp firmness } \\
(\mathrm{N})\end{array}$ \\
\hline IBA & 1000 & $2.5 \mathrm{ab}^{\mathrm{z}}$ & 50.0 & $2.65 \mathrm{~d}^{2}$ \\
& 5000 & $1.8 \mathrm{a}-\mathrm{d}$ & 66.7 & $3.92 \mathrm{~b}-\mathrm{d}$ \\
$2,4-\mathrm{D}$ & 100 & $2.7 \mathrm{ab}$ & 83.3 & $5.98 \mathrm{a}$ \\
& 1000 & $0.8 \mathrm{de}$ & 33.3 & $5.59 \mathrm{a}$ \\
$2,4,5-\mathrm{T}$ & 100 & $2.2 \mathrm{a}-\mathrm{c}$ & 83.3 & $5.20 \mathrm{ab}$ \\
& 1000 & $0.0 \mathrm{e}$ & 00.0 & $4.70 \mathrm{a}-\mathrm{c}$ \\
$\mathrm{GA}_{3}$ & 10 & $1.2 \mathrm{~b}-\mathrm{d}$ & 33.3 & $3.14 \mathrm{~cd}$ \\
& 100 & $0.0 \mathrm{e}$ & 00.0 & $2.84 \mathrm{~d}$ \\
BAP & 10 & $2.8 \mathrm{ab}$ & 83.3 & $2.64 \mathrm{~d}$ \\
& 100 & $0.3 \mathrm{e}$ & 16.7 & $2.45 \mathrm{~d}$ \\
Daminozide & 500 & $2.5 \mathrm{ab}$ & 50.0 & $3.33 \mathrm{~d}$ \\
& 5000 & $0.8 \mathrm{de}$ & 33.3 & $3.82 \mathrm{~b}-\mathrm{d}$ \\
Mepiquat chloride & 25 & $3.2 \mathrm{a}$ & 66.7 & $3.82 \mathrm{~b}-\mathrm{d}$ \\
& 100 & $2.5 \mathrm{ab}$ & 50.0 & $2.26 \mathrm{~d}$ \\
\hline
\end{tabular}

${ }^{2}$ Mean separation within columns by Duncan's multiple range test at $P \leq 0.05$. 
Subtropical \& Tropical Horticulture

Table 3. Effect of coatings on weight loss, internal $\mathrm{CO}_{2}$ and $\mathrm{C}_{2} \mathrm{H}_{4}$ concentrations, and dehiscence of durian fruit stored at $29 \mathrm{C}$ for various amounts of time.

\begin{tabular}{|c|c|c|c|c|c|c|c|c|c|}
\hline \multirow{3}{*}{$\begin{array}{l}\text { Coating } \\
\text { material }\end{array}$} & \multirow{3}{*}{$\begin{array}{c}\text { Concn } \\
(\%)\end{array}$} & \multirow{3}{*}{$\begin{array}{c}\text { Wt loss } \\
\text { at } 9 \text { days } \\
(\%)\end{array}$} & \multicolumn{3}{|c|}{$\mathrm{CO}_{2}(\%)$} & \multicolumn{3}{|c|}{$\mathrm{C}_{2} \mathrm{H}_{4}(\mathrm{ppm})$} & \multirow{3}{*}{$\begin{array}{c}\text { Dehiscence score } \\
\text { at } 9 \text { days }\end{array}$} \\
\hline & & & \multicolumn{3}{|c|}{ Storage duration (days) } & \multicolumn{3}{|c|}{ Storage duration (days) } & \\
\hline & & & 3 & 6 & 9 & 3 & 6 & 9 & \\
\hline Control & --- & $23.8 \mathrm{a}^{\mathrm{z}}$ & $9.3 \mathrm{e}^{\mathrm{z}}$ & $20.2 \mathrm{~d}^{\mathrm{z}}$ & $40.6 \mathrm{f}^{2}$ & $10.8 b^{z}$ & $24.9 b c^{z}$ & $33.9 \mathrm{a}^{\mathrm{z}}$ & $4.7 \mathrm{a}^{\mathrm{z}}$ \\
\hline Semperfresh & 1 & $9.8 \mathrm{~d}$ & $18.1 \mathrm{a}$ & $32.2 \mathrm{a}$ & $60.2 \mathrm{a}$ & $6.1 \mathrm{~d}$ & $11.1 \mathrm{e}$ & $17.7 \mathrm{e}$ & $0.0 \mathrm{~b}$ \\
\hline \multirow[t]{2}{*}{ Apple wax } & 100 & $12.5 \mathrm{~cd}$ & $18.8 \mathrm{a}$ & $28.7 \mathrm{~b}$ & $58.8 \mathrm{a}$ & $8.9 \mathrm{c}$ & $15.8 \mathrm{~d}$ & $20.3 \mathrm{~d}$ & $1.6 \mathrm{~b}$ \\
\hline & 50 & $16.6 \mathrm{~b}$ & $11.4 \mathrm{~cd}$ & $22.4 \mathrm{c}$ & $45.5 \mathrm{c}$ & $10.4 \mathrm{~b}$ & $23.9 \mathrm{c}$ & $30.7 \mathrm{c}$ & $4.5 \mathrm{a}$ \\
\hline \multirow[t]{2}{*}{ Storage wax } & 100 & $11.4 \mathrm{~cd}$ & $15.9 \mathrm{~b}$ & $29.5 \mathrm{~b}$ & $55.3 \mathrm{~b}$ & $10.0 \mathrm{~b}$ & $17.0 \mathrm{~d}$ & $21.0 \mathrm{~d}$ & $0.4 \mathrm{~b}$ \\
\hline & 50 & $13.3 \mathrm{bc}$ & $12.7 \mathrm{c}$ & $20.9 \mathrm{~cd}$ & $43.3 \mathrm{~d}$ & $9.2 \mathrm{~d}$ & $25.9 \mathrm{a}$ & $31.9 \mathrm{a}-\mathrm{c}$ & $4.9 \mathrm{a}$ \\
\hline \multirow[t]{2}{*}{ Sta-fresh } & 20 & $16.0 \mathrm{~b}$ & $10.4 \mathrm{de}$ & $20.1 \mathrm{~d}$ & $41.1 \mathrm{ef}$ & $12.9 \mathrm{~d}$ & $25.4 \mathrm{ab}$ & $31.1 \mathrm{bc}$ & $3.9 \mathrm{a}$ \\
\hline & 10 & $16.6 \mathrm{~b}$ & $11.1 \mathrm{~cd}$ & $19.8 \mathrm{~d}$ & $42.2 \mathrm{de}$ & $13.2 \mathrm{a}$ & $22.1 \mathrm{c}$ & $32.3 \mathrm{ab}$ & $4.6 \mathrm{a}$ \\
\hline
\end{tabular}

${ }^{2}$ Mean separation within columns by Duncan's multiple range test at $P \leq 0.05(\mathrm{n}=15)$.

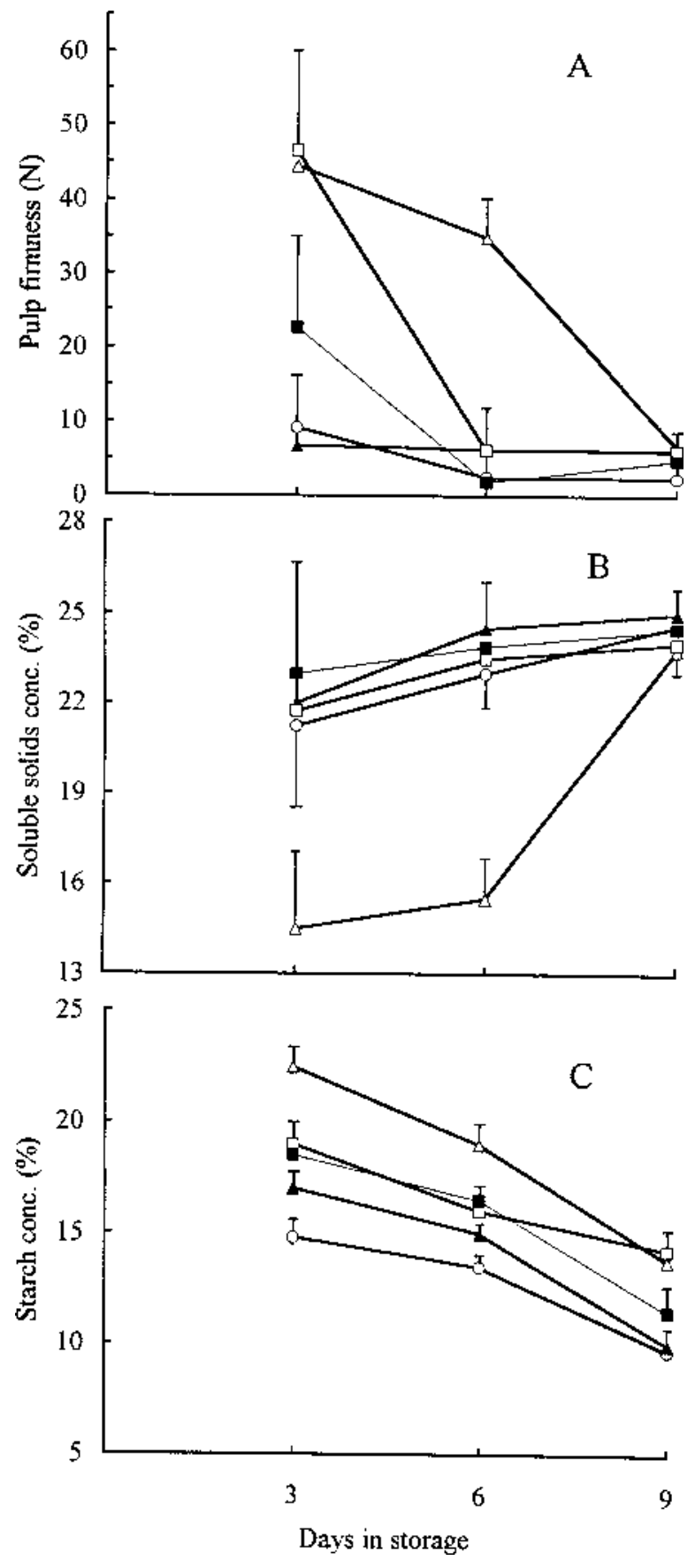

Fig. 4. (A) Changes in pulp firmness and (B) soluble solids and (C) starch concentrations of durian fruit coated with various materials and stored at $29 \mathrm{C}, 70 \%$ to $80 \%$ relative humidity. (O) Control, $(\Delta)$

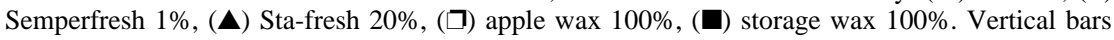
represent SD $(\mathrm{n}=15)$.
Coating materials were effective in preventing durian fruit dehiscence. The coatings prevented fruit weight loss and created a modified atmosphere (high $\mathrm{CO}_{2}$ and presumably low $\mathrm{O}_{2}$ ) in the fruit. This atmosphere modification may interfere with ethylene production and action (Yang, 1985). The main factor influencing durian dehiscence was ethylene production because coating with apple wax $50 \%$, storage wax 50\%, and Stafresh $10 \%$ and $20 \%$ reduced weight loss by $30 \%$ of the control, but internal ethylene concentration and dehiscence scores were not different (Table 3 ) from those of the control. In addition, weight loss was similar in durian fruit, whether treated or not treated with ethylene (Fig. 3), but those that were treated had higher dehiscence scores.

In commercial practice, $\mathrm{GA}_{3}$ alone could be used for a shipment of fully mature fruit to markets that prefer such nondehiscent fruit with ripe pulp. For distant markets, such as America and Europe, or markets within Thailand that prefer less ripe fruit, waxes could be used to delay ripening. A combination of wax and $\mathrm{GA}_{3}$ should be tested in future experiments to extend durian storage life.

\section{Literature Cited}

Abeles, F.B. 1973. Ethylene in plant biology. Academic, New York.

Association of Official Analytical Chemists. 1984. Official methods of analysis of the association of official analytical chemicals. Assn. Official Analytical Chemists, Arlington, Va.

Booncherm, P. and J. Siriphanich. 1991. Postharvest physiology of durian pulp and husk. Kasetsart J. (Natural Sci.) 25:119-125.

Crane, J.C. and B.T. Iwakiri. 1982. Shell dehiscence in pistachio. HortScience 17:797-798.

Dept. of Customs. 1991. Foreign trade statistics of Thailand: December 1989. Dept. of Customs, Bangkok, Thailand.

Dostal, H.C. and A.C. Leopold. 1967. Gibberellin delays ripening of tomatoes. Science 158:15791580.

Tongdee, S., C. Suwanagul, A. Neamprem, S. Bunruengsri, and U. Bunruengsri. 1990. Effect of surface coatings on weight loss and internal atmosphere of durian (Durio zibethenus Murr.) fruit. ASEAN Food. J. 5:103-107.

Vendrell, M. 1970. Acceleration and delay of ripening in banana fruit tissue by gibberellic acid. Aust. J. Biol. Sci. 23:553-559.

Wood, W. 1986. Use of ethephon and NAA for inducing early shuck dehiscence of pecan. J. Amer. Soc. Hort. Sci. 111:533-537.

Yang, S.F. 1985. Biosynthesis and action of ethylene. HortScience 20:41-45. 